\title{
Factor analysis of passengers' satisfaction at Murtala Muhammed Airport (MMA2)
}

\begin{abstract}
This study examines the interrelationships of complex factors influencing passengers' satisfaction at Murtala Muhammed Airport (MMA2). The airport is the domestic and only concessioned airport terminal in Nigeria. Theoretical evidence was examined and factor analysis was carried out to identify the main groups of factors affecting passengers' satisfaction at the Airport. It also elucidates the model and application of factor analysis. The study was conducted using questionnaires to collect the required data at the airport terminal through a convenience sampling technique. Out of six hundred and fifty-seven (657) questionnaires distributed, five hundred and fourteen (514) valid questionnaires were returned for data analysis.

The findings revealed the most crucial eight factors affecting passenger satisfaction in MMA2, and are: Immigration staff attitude, Priority baggage delivery efficiency, Efficiency of available public transport options, Immigration and queuing times, Security and safety standards, Television and entertainment facilities, Internet facilities and WIFI availability, and Washroom and shower facilities. From the findings, recommendations were suggested that among thirty nine airport services listed in the service benchmark for global airport, managers of MMA2 should provide quality services with respect to: Immigration staff attitude; Priority baggage delivery efficiency; Efficiency of available public transport options; Immigration and queuing times; Security and safety standards; Television and entertainment facilities; Internet facilities and WIFI availability; and Washroom and shower facilities as they are crucial to satisfying the passengers.
\end{abstract}

Keywords: airport development, customer satisfaction, factor analysis, Murtala Muhammed Airport
Volume 4 Issue I - 2020

\author{
Adeniran Adetayo O, Stephens Mobolaji S, \\ Akinsehinwa Feyisola $\mathrm{O}$ \\ Department of Transport Management Technology, Federa \\ University of Technology Akure, Nigeria
}

\begin{abstract}
Correspondence: Adeniran Adetayo O, Department of Transport Management Technology, Federal University of Technology Akure, Nigeria, Tel +2347036196773,
\end{abstract} Email adeniranao@futa.edu.ng

Received: March 16, 2020 | Published: April 09, 2020

\section{Introduction}

Recently, the world aviation industry is gaining more attention, as it is contributing significantly to international, regional, and national economies. The new trend in aviation is the shifting of airport operations and management from public airport ownership to private airport ownership which gives room for optimum utilization of resources, efficient decision making, and innovation and enable major transformation of the enterprise. It is pertinent to note that airport is regarded as an enterprise if its services are being delivered in an enterprising manner. As a result of this, copious innovative strategies alongside a more consumer-friendly airport dynamic approach enhances higher degree of delivered service that is consumed by passengers. ${ }^{1}$

In modern economics, mobility of people is encouraged which sequentially enhances improvement in the national level. As a result of this, there is a positive advancement in the Nigerian aviation industry, and it is likely to bring out a stronger impact on the economy. According to Oxford Economics, ${ }^{2}$ in 2012, aviation industry of Nigeria accounted for 198 billion or $0.6 \%$ of GDP (gross domestic product), 159 thousand workplaces (direct, indirect, supply chain, and catalytic effects), as well as $\$ 85$ billion in taxes. ${ }^{3}$

The delivery of quality air services to passengers has turn out to be the primary strategy for achieving competitive advantage which enhances sustainable growth for the airports and seamless air travel operations for both the international and domestic airlines. The delivery of quality air services offered by airports to passengers is among the major factors that brings major air carriers to an air hub. ${ }^{4-7}$
In the situation of economic pressure that was prompted by the global financial crisis, it could be devastating for airlines to provide service quality package that passengers would often prefer, this is particular for the executive carriers that have already established goodwill and have cemented their service offerings in the mind of their users, such carrier have been able to achieve word of mouth (WOM) and customer loyalty (CL). Air passengers of such airlines are expected to have higher expectations regarding the quality of service that will be delivered. Giving out the quality service will be among the challenging issue when attracting and retaining passengers in the face of absolute competition. It is crucial to note that it will be more challenging for lower carriers that have not yet dominated the air travel market.

Research has revealed that the aspects of the overall service offered by airlines to passengers are crucial determinant for passengers' decisions regarding the choice of airlines..$^{8-10}$ According to Adam \& John, ${ }^{11}$ airline managers are expected to comprehend the value placed by passengers set on different aspects of service quality mix as these choices will directly affect an airline's strategic positioning.

It was proposed that the management at Murtala Muhammed Airport shift the focus of their planned activities more towards increasing the service quality. The resulting increased passenger satisfaction would positively influence the competitive advantage of the airport. As a result, the newly gained passenger traffic and the reserved passenger traffic may attract new carriers, investment and larger portion in the Nigerian aviation market.

Several variables are proposed to explain the complex situation, interconnections and interrelationships of variables, especially in 
satisfaction and service quality study. In this regard, the few basic variables and propositions central to understanding remain to be determined. The systematic dependencies and correlations among these variables are charted only on presence-absence or rank order scales data. In a situation where the researcher is being confronted with entangled behaviour, unknown interdependencies, masses of qualitative and quantitative variables, and bad data, many social scientists turn towards factor analysis to uncover characteristic features of major social and international phenomena. ${ }^{12}$

Factor analysis is a quantitative technique that is designed to enlighten and expand the essential structure of a given phenomena, most especially when it has to do with complex relationship among several variables. The discovery of this analytical technique is over a century, ${ }^{13}$ and thus remain pertinent with evolving modifications. Despite the key function of factor analysis across different field of study, it has often been misconstrued, miscomprehended ${ }^{14}$ and misapplied. Even though factor analytic methods are shabby techniques, they have the prospect of achieving important clue regarding the debate of importance rating analysis.

This is possible because factor analysis can concurrently manage diverse variables with random error and invalidity, and unravel multifaceted interdependencies and interrelationships into their foremost and different regularities. Factor analysis involves the following terminologies such as correlation matrix, communality, eigen values, factor rotation, factor loadings, total variance explained and others.

In importance study of the service industry, service indicators are usually set as indicators to assess the performance of services rendered, and out of which an organization might decide to prioritize some services. Given identifying the most significant services, some studies adopt relative importance index which seems to be devoid of strong statistical analysis. Many studies have been conducted on factor analysis; most of these articles are carried out in western countries.

Few of the abridged studies were found available in Nigeria and other similar countries, but no detailed study is seen in assessing passengers' satisfaction. Therefore, this will somewhat cover the research gap by reducing the airport services to identify the important services of the domestic terminal of Murtala Muhammed Airport with the use of factor analysis. This airport was studied because it is the domestic and only concessioned airport terminal in Nigeria Factor analysis was used because there is no conception of theoretical hypothesis, and the underlying data is a common structure. It is believed that this study will assist those who need to read and comprehend research articles on factor analysis, as well as those that might find it desirable to apply factor analysis in importance study. The specific objectives are to elucidate the model and approach of factor analysis for identifying the crucial factors influencing passengers' satisfaction.

\section{Literature review}

The study of two constructs "passengers' satisfaction" and "service quality" is a noteworthy aspect that must be critically considered by the management of airports because its' crucial nature results to competitive advantage, increased income and overall airport sustainable growth. In the present competitive business environment, there is high-quality service which often results to increased consumer satisfaction. It often creates advantage of positive word of mouth and increased loyalty. ${ }^{1}$ According to Dolnicar et al., ${ }^{15}$ it is commonly believed that higher satisfaction of services can appreciably increase customer loyalty and recurring purchases.

According to Gilbert \& Wong, ${ }^{16}$ in order to attain this goal, the management of airport must be acquainted with passenger expectations for services offered. Service quality is the entire impression regarding the efficiency of services rendered by a company that is rated by the customers (passengers). ${ }^{17}$ Therefore, having a better understanding of what passengers expect is the most crucial step in defining and delivering the high-quality service. An evaluation of service quality by customers is among the suitable means to verify their service expectations and service perceptions. ${ }^{18}$ Fulfilled or improved expectations of passengers results to their satisfaction with regard to the airport services the provided.

Passenger satisfaction is a decision that is realized regarding an explicit service encountered. ${ }^{19}$ Passenger satisfaction of services emanates when an organization is able to provide benefits that exceed original expectations of customers, and this is usually perceived as utility or marginal utility (value-added). Experiences gathered around the airport terminal seem to be something special for passengers, as they encompass a multiplicity of choices of services to select from. Examples are, duty-free or regular shopping, prayer rooms, numerous eateries, museums, club-rooms, information and transfer desks, smoking areas, security, airline offices, support for passengers with disabilities, restrooms, walkways, gates, all types of transportation and parking areas. ${ }^{1,20}$

The airport services may meet or even surpass the needs of the passengers. For that reason, it is likely that airport administrators and managers are endlessly in quest of new services, innovating services for the purpose of enhancing service/product differentiations which will enhance competition. There is a variety of options to expand services, and doing that better serve to exist, but attract more passengers. Having exceptional passenger experience could even make the passenger pick a particular airport among the rest for the leisure purposes or even as a preferred point for a transfer in future. On the contrary, in case the passenger is not satisfied with the time spent at a particular airport, the passenger may reconsider his decision to arrive there in favour of another airport with a better suitable profile. This may reduce the goodwill of the airport and militate against the readiness to recommend the airport to other passengers or airport users. Hence, it will negatively affect the airport's development. Thus, excellent passenger satisfaction is one of the best assets for airport business in a competitive environment. Marketing theory suggests that increasing customer loyalty and its retention is a chief key to the ability of a company to generate profit. ${ }^{21}$

The Airports Council International questionnaire contains fifty-one (51) exceptionally detailed criteria for evaluating airport. However researchers Correia et al., ${ }^{22}$ stress only seven common factors: waiting time; processing time; walking time; walking distance; level changes; orientation/information; and space available for passengers. The factors considered as airport dimensions are important but insufficient to be used as variables for the evaluation of passenger satisfaction with their experience. Another attempt to classify the factors influencing passenger satisfaction has been made by De Barros et al. ${ }^{23}$ They created a questionnaire to evaluate the passengers' subjective experience. Passengers were asked to rate their experience accordingly to twenty-two (22) offered factors that were previously classified by authors into six categories: transit; restrooms; restaurants and bars; duty-free shops; security; and other facilities. 
Furthermore, Sergejs \& Ksenija ${ }^{1}$ revealed that the most important five factors affecting it are: availability of telecommunications; effective wayfinding signs; cleanliness of restrooms; courtesy of staff; and availability of staff out of forty-six (46) evaluating factors at RIGA International Airport (Latvia). Although the passengers were also asked to rate their overall experience at the airport, the factors considered as airport dimensions are insufficient to be used as variables for the evaluation of passenger satisfaction, the behaviour of respondents was not taken into consideration. The Table 1 below shows the summary of some studies conducted on passengers' satisfaction of airport services.

Table I Summary of empirical studies

\begin{tabular}{|c|c|c|c|c|c|}
\hline Topic & $\begin{array}{l}\text { Airport } \\
\text { Country }\end{array}$ & Methodology & Variables & Models & Findings \\
\hline $\begin{array}{l}\text { Passengers' } \\
\text { expectations of } \\
\text { airport service quality }\end{array}$ & $\begin{array}{l}\text { Newyork's } \\
\text { Kennedy } \\
\text { Airport and } \\
\text { Liverpool's } \\
\text { John Lennon } \\
\text { Airport, USA }\end{array}$ & $\begin{array}{l}\text { Qualitative and } \\
\text { quantitative } \\
\text { research }\end{array}$ & $\begin{array}{l}\text { Eight (8) airport } \\
\text { service indicators } \\
\text { on Seven-point scale }\end{array}$ & $\begin{array}{l}\text { Exploratory } \\
\text { and } \\
\text { Confirmatory } \\
\text { Factor Analysis } \\
\text { (CFA) }\end{array}$ & The average age of respondent is 48 years. ${ }^{24}$ \\
\hline
\end{tabular}

Passenger' expectations of airport service quality are a multidimensional, hierarchical construct that includes three key dimensions: function, interaction and diversion.

UAE based airports are much more friendly

Methods and tools used by UAE's federal government and various local governments to improve the passengers' satisfaction with regard to the aviation industry

Incheon International

Importance and satisfaction of airport selection attributes
Descriptive study, questionnaire

Three (3) airport variables
Airport and Gimpo International Airport, Korea
Chi-square test was used to establish the difference between the three airports when compared to other international airports in terms of security checks. Both Abu Dhabi and Dubai International Airports were seen by passengers to have a good number of clear directional signs, whereas many of the respondents agreed that Sharjah Airport was very confusing due to the lack of directions and guides available to help the passengers find their way around the airport. ${ }^{25}$

\section{Gap} analysis and importanceperformance analysis
The satisfaction was higher than the importance in terms of accessibility and facilities in Gimpo International Airport. ${ }^{26}$

The satisfaction was higher than the importance in terms of operation, facilities and spatiality in Incheon International Airport.

68 percent of the respondents were women while 32 percent were men. The biggest age group with 58 percent was young people between the ages of 18-24 years, 38 percent was said to be in the category of age $25-34 .{ }^{27}$

High level of customer dissatisfaction about comfort and convenience in the airport terminal, they were also displeased with the state of interior in the terminal, and respondents are not satisfied with the size of airport premises. On the overall level of satisfaction on the airport terminal facilities, 44 percent of respondents were satisfied. 
Table Continued

\begin{tabular}{|c|c|c|c|c|c|}
\hline Topic & $\begin{array}{l}\text { Airport } \\
\text { Country }\end{array}$ & Methodology & Variables & Models & Findings \\
\hline $\begin{array}{l}\text { Determinants } \\
\text { of customers' } \\
\text { satisfaction using } \\
\text { Analytic Hierarchical } \\
\text { Process (AHP) model }\end{array}$ & $\begin{array}{l}\text { Murtala } \\
\text { Muhammed } \\
\text { Airport } 2 \\
\text { (MMA2) in } \\
\text { Lagos }\end{array}$ & $\begin{array}{l}\text { Convenience } \\
\text { sampling and } \\
\text { snowballing } \\
\text { techniques. }\end{array}$ & $\begin{array}{l}\text { Eighteen (I8) } \\
\text { airport and airline } \\
\text { factors }\end{array}$ & $\begin{array}{l}\text { AHP model } \\
\text { was used to } \\
\text { analyze the } \\
\text { data obtained } \\
\text { by using } \\
\text { descriptive } \\
\text { statistics and } \\
\text { the Expert } \\
\text { Choice }\end{array}$ & $\begin{array}{l}\text { Nine point Likert scale was used. Orderliness } \\
\text { and cleanliness of check-in area services } \\
\text { at transit point are factors that increase } \\
\text { passengers' satisfaction. }{ }^{28}\end{array}$ \\
\hline $\begin{array}{l}\text { Users' perceptions of } \\
\text { service quality }\end{array}$ & $\begin{array}{l}\text { Murtala } \\
\text { Muhammed } \\
\text { International } \\
\text { Airport } \\
\text { (MMIA), } \\
\text { Lagos, Nigeria }\end{array}$ & $\begin{array}{l}\text { Descriptive } \\
\text { statistics and } \\
\text { questionnaire }\end{array}$ & $\begin{array}{l}\text { Sixteen (I6) airport } \\
\text { indicators }\end{array}$ & $\begin{array}{l}\text { Accidental } \\
\text { random } \\
\text { sampling }\end{array}$ & $\begin{array}{l}\text { Inadequacy of access from origin to airport, } \\
\text { Delay /long queue for ticket purchasing, High } \\
\text { cost access to airport, Inadequate airport } \\
\text { facilities / services (specify), Irregular flight } \\
\text { schedule, Cancellation of flight. }^{29}\end{array}$ \\
\hline $\begin{array}{l}\text { Passengers' } \\
\text { satisfaction survey on } \\
\text { the domestic Airports }\end{array}$ & $\begin{array}{l}\text { Domestic } \\
\text { Airports, } \\
\text { Nigeria }\end{array}$ & Descriptive study & $\begin{array}{l}\text { Twenty-six (26) } \\
\text { airport indicators }\end{array}$ & $\begin{array}{l}\text { Five }(5) \text { points } \\
\text { likert scale }\end{array}$ & $\begin{array}{l}\text { Airport facilities are in need of improvement. } \\
\text { The overall level of respondent satisfaction is } \\
\text { satisfied with } 44 \text { percent }\end{array}$ \\
\hline $\begin{array}{l}\text { Travelers' perception } \\
\text { on airport satisfaction }\end{array}$ & $\begin{array}{l}\text { Hong Kong } \\
\text { International } \\
\text { Airport } \\
\text { (HKIA) }\end{array}$ & $\begin{array}{l}\text { Descriptive study, } \\
\text { questionnaire }\end{array}$ & $\begin{array}{l}\text { Fourteen (14) } \\
\text { airport factors }\end{array}$ & $\begin{array}{l}\text { Gap score } \\
\text { analysis }\end{array}$ & $\begin{array}{l}\text { Tangibility, reliability, responsiveness, and } \\
\text { assurance were the most concerned } \\
\text { factors regarding airport service quality } \\
\text { while empathy was the least satisfied by } \\
\text { the travelers. It also shows that the older } \\
\text { travelers, the business travelers, and the } \\
\text { individual travelers are expressed lesser } \\
\text { satisfaction of HKIA. Factors like art display } \\
\text { and children play area respectively were less } \\
\text { importance. Also, security was found to be } \\
\text { the most importance factor. }\end{array}$ \\
\hline
\end{tabular}

Survey

methodology

Cross-sectional

Relationship

between dimensions

of service quality

Nigerian

data were collected

at four different

international

Fifteen airport

indicators

Regression

Although the relationship between each of the dimensions of service quality and passengers' satisfaction is significant at 5 percent critical region, the multiple correlation coefficient ranges from weak. ${ }^{31}$

satisfaction

airports with the

aid of structured

questionnaire

Assessment

of passengers'

satisfaction and

service quality in

Murtala

Murtala Muhammed

Muhammed

Airport

Purposive sampling

Thirty nine airport

(MMA2),

technique

indicators

Servqual model

Passengers are satisfied with the Efficiency of available public transport options; Taxi availability and prices; Immigration and queuing times; Prevent lost luggage services; Security and safety standards; Ease of transit through the airport; ${ }^{4}$

Lagos, Nigeria:

application of

Lagos, Nigeria:

Baggage delivery times; Smoking policy and standard of smoking lounges. However, there is need to improve the Standard of physically impaired facilities; and Priority baggage delivery efficiency. 
Table Continued

\begin{tabular}{|c|c|c|c|c|c|}
\hline Topic & $\begin{array}{l}\text { Airport } \\
\text { Country }\end{array}$ & Methodology & Variables & Models & Findings \\
\hline $\begin{array}{l}\text { Gap analysis } \\
\text { of passengers' } \\
\text { satisfaction and } \\
\text { service quality in } \\
\text { Murtala Muhammed } \\
\text { International Airport, } \\
\text { Lagos, Nigeria }\end{array}$ & $\begin{array}{l}\text { Murtala } \\
\text { Muhammed } \\
\text { International } \\
\text { Airport } \\
\text { (MMIA), } \\
\text { Lagos, Nigeria }\end{array}$ & $\begin{array}{l}\text { Purposive sampling } \\
\text { technique }\end{array}$ & $\begin{array}{l}\text { Thirty nine airport } \\
\text { indicators }\end{array}$ & Gap analysis & $\begin{array}{l}\text { The study revealed that the five most } \\
\text { satisfied airport services as rated by } \\
\text { passengers were Efficiency of available } \\
\text { public transport options, Getting to and } \\
\text { fro airport with ease, Availability of luggage } \\
\text { trolleys, Baggage delivery times, and Priority } \\
\text { baggage delivery efficiency. Also, the five } \\
\text { most dissatisfied airport services as rated by } \\
\text { passengers were Courtesy and attitude of } \\
\text { security staff, Television and entertainment } \\
\text { facilities, Seating facilities throughout the } \\
\text { terminal, Language skills for airport staff, and } \\
\text { Business center facility. It was revealed that } \\
\text { passengers were satisfied with the overall } \\
\text { level of airport service quality. }\end{array}$ \\
\hline
\end{tabular}

After critical reviewing of the previous works that were earlier mentioned, a list of thirty-nine (39) airport evaluating factors was adopted from SKYTRAX which is a world benchmark for services rendered in the airport. It is suggested that these specific factors could be generalized and united into broader categories. Then there was passengers' satisfaction survey, where the given numbers of airport operations influencing factors were included into question statements. The task was to reveal the passengers' opinion on both general experience and specific factors (subjective criteria). The received results created the needed pool of data for the conducting of factor analysis, which in its turn helped to find the complex factors. The results of this study could assist airport managers to better serve their passengers, develop and monitor service quality and gain the highest level of customer satisfaction, and appreciate the application of factor analysis.

\section{Methodology}

\section{Research design}

For this study, the airport services were coined out to form questions for passengers' survey. The questions contained some contexts regarding passengers' use of aviation and non-aviation services while spending time at the airport, it captures their demographic factors satisfaction, as well as the purpose of trip. All MMA2 passengers were considered as the study population and the sampling frame entails the passengers who have experienced the airport services at the moments of conducting the survey. Respondents for the study were selected based on convenience sampling technique.

According to Henry; ${ }^{33}$ Saunders et al. ${ }^{34}$ convenience sampling belong to non-probability sampling technique, it is also referred to as grab sampling, accidental sampling, opportunity sampling, or availability sampling. It is a type of non-probability sampling that involves the sample being drawn from part of the population that is close to hand or easy to reach. ${ }^{4}$ This method is appropriate because air passengers are usually time conscious and therefore, targeted passengers that are available and willing to participate in the survey.

To determine the appropriate sample size for a large (infinite) population at the airport and an uncertain number of populations that will be met at the airport, judgment about the confidence level and the maximum error allowance was made, and the equation below was applied to determine the sample size as adapted from Zikmund. ${ }^{35}$ According to Zikmund, ${ }^{35}$ the error allowances are usually determined and the suitable one will be chosen based on the discretion of the researcher. The chosen error allowance of 0.04 was employed because it will give a more desired sample size that will justify the factor analysis model. The equation below was used to achieve the sample size:

The formulae for achieving sample size $n=Z^{2} / 4 E^{2}$

where;

$\mathrm{n}=$ sample size;

$\mathrm{Z}=\mathrm{Z}$ score for the confidence interval (2.05);

$\mathrm{E}=$ Error allowance (0.04).

When inserted into the formula, Sample Size will be 656.6406 , and approximately 657. Regarding the recommendations of the sample size for factor analysis, Guilford ${ }^{36}$ noted that sample size should be at least 200, while Cattell ${ }^{37}$ made recommendation of three to six subjects per item, with a minimum of 250 number of sample size. Furthermore, Comrey \& Lee $^{38}$ provide the following guidance with respect to the determination of sample size adequacy: such that the sample size of hundred (100) is poor; sample size of two hundred (200) is fair; sample size of three hundred (300) is good; sample size of five hundred (500) is very good; and sample size of one thousand (1000) or more is excellent. In this study, the sample size of six hundred and fifty seven (657) is adequate for factor analysis and reporting as rooted in earlier studies.

It is therefore crucial that the questionnaire distribution targeted six hundred and fifty-seven respondents who are passengers in the airport and must have experienced the airport facilities. The questionnaire survey was conducted for the period spanning between $21^{\text {st }}$ of March and $28^{\text {th }}$ of April, 2018. The evaluation scale is ordinal, and it is composed of ten judgement scales.

The received sample was 514 questionnaires were retrieved from the respondents. However, after manual processing, all the received questionnaires were selected valid which represent 78.2 per cent returned. This is validated in accordance to the studies of by 
Mugenda; ${ }^{39}$ Adeniran \& Fadare ${ }^{4}$ that a response rate of 50 per cent and above is adequate for data analysis and reporting. The collected data was processed and analyzed using the Statistical Package for Social Science (SPSS Version 20). Additionally, the factor analysis was used as a statistical method for data processing.

\section{Model specification}

\section{Factor analysis}

Factor analysis is a model that belongs to the family of General Linear Model (GLM) procedures. It has the same underlying principles with multiple regressions which can be achieved with interval or near -interval data, latent variables, and proper specification including relevant variables and excluding extraneous ones. It can be employed to determine the linear relationships, the lack of high multicollinearity, and multivariate normality. It is a generic term for a family of statistical techniques concerned with the reduction of a set of observable variables in terms of a small number of latent factors. It has been developed primarily for analysing relationships among several measurable entities (such as survey items or test scores). ${ }^{12}$

The aim of all factor analytic techniques is to explain patterns of covariation among observed or manifest (i.e., directly measured) variables using unobserved or latent constructs. That is to say, given that responses to some stimuli (e.g., responses to transport service interview questions or inventories) show patterns of covariation, it is reasonable to hypothesize that there is an explanation for this patterning (e.g., a socio-demographic characteristic). This was exactly the logic that prompted Spearman ${ }^{13}$ to develop factor analysis. He had observed that those individuals who performed well on one mental test tended to perform well on others, which gave rise to his general theory of intelligence and the need for a quantitative method to test it. Factor analysis was thus born. As factor analysis applies to the study of importance analysis, it is employed to identify the major services that are needed to be prioritized.

Factor analysis is referred to as the statistical approach that is employed to minimize a large cloud of data to a little amount of complex factors (in this study, the complex factors are reflecting on passenger satisfaction), for the purpose of detecting the presence of substantial patterns among the initial variables ${ }^{40}$ and to elicit the crucial factors representing relationships between the sets of many interrelated variables. ${ }^{41}$ The analytical model can produce descriptive representations of data matrices, that help in detecting the presence of meaningful patterns among a set of variables and to study relationships among the attributes. ${ }^{42}$ This use of factor analysis is called "R-type" and is well known in the social sciences. It is available in personality studies of Cattell et al; $;{ }^{37}$ Costa and McCrae (1992), ${ }^{38}$ and intelligence studies of Guilford; ${ }^{36}$ Thrustone. ${ }^{43}$

\section{Types or usage of factor analysis}

The usage of factor analysis in pointing out the relationships between the entities is referred to as "Q-type". This type if factor analysis is usually employed with less frequency than R-type, and it is not usually employed by social science researchers. It is usually adopted in situations where the profile of the attributes or the pattern of scores that an individual obtains over a set of measures, instead of focusing on the analysis or description of a single variable at a particular time. ${ }^{14}$ The use of factor analysis has risen up into a sophistication and complexity, and now includes a family of related techniques that differ in a number of ways (e.g., confirmatory and exploratory estimation techniques). In spite of the various techniques of estimation, they are targeted towards the same goal.

Factor analysis can also be understood to fall within a broader organization of latent variable models, which includes structural equation modelling, item response theory and latent trait models, latent class/profile analysis, and perhaps most generally factor mixture modelling. ${ }^{44}$ It can, therefore, be noted that factor analysis emanated with exploratory factor analysis (EFA) and confirmatory factor analysis (CFA), ${ }^{45}$ and later with exploratory structural equation modelling (ESEM) ${ }^{46}$ The EFA, CFA, and ESEM are most appropriate for multivariate cross-sectional data analysis which is mostly realized from inventories of report and survey interviews.

1. Data analyst may have no theoretical hypothesis in mind when adopting factor analysis and is simply searching for a common structure underlying the data. The use of factor analysis in this manner is referred to as exploratory.

2. Factor analysis may be employed in a case where the data analyst has some prior theoretical information on the common structure underlying the data which is in consonance with the confirmation of hypothesized structure. The use of factor analysis in this manner is referred to as confirmatory. ${ }^{12,14}$

3. Concerning exploratory structural equation modelling, factor analytic models can be mostly understood as falling along an exploratory to confirmatory spectrum. Hence, factor analysis can be fully exploratory (EFA), fully confirmatory (CFA), or some hybrid of the EFA and CFA which is referred to as ESEM.

\section{Terminologies of factor analysis}

\section{Factor loadings}

The factor loadings can also referred to as component loading in Principal Component Analysis (PCA). They are the correlation coefficients between the variables (rows) and factors (columns) which show the degree of strength and direction of the variables regarding the factors to be considered. PCA is the wide-ranging technique that is used for grouping the variables under the fewer unrelated factors. It is pertinent to note that variables with factor loading that are more than 0.5 are usually grouped under a particular factor. Debasish ${ }^{47}$ noted that a factor loading is a correlation (cause and effect relationship) that is flanked between the original variable with a specific factor and it is the key to having better understanding about the nature of that particular factor being considered.

When making inference from the factor loads, it is expedient to be critical about the examination of loadings for the aim of examining the strength and degree of relationships. Factors can be identifies from the loadings with higher values; nonetheless, it is also more essential to find out lower loadings and the zeros so as to confirm the identification and classification of the factors. ${ }^{48}$ In the loadings, there is need for small number of item cross-loadings (split loadings) so that each factor defines a different bunch of interconnected or interrelated variables. The term "cross-loading" occur when a variable loads on factors at $\geq 0.32 .{ }^{49}$

An additional selection is to make decision using a significant loading that is cut-off for making explanation simpler. The indications of the factor loadings represent the strength (potency) and direction (trend) of relationship (correlation) and does not have an effect on the interpretation and explanation on the degree of factor loading 
or the number of factors that should be maintained. ${ }^{50}$ An illustration that is established by Costello \& Osborne ${ }^{49}$ noted that in a situation where there is a factor referred to as "anxiety" and the variables that load high on this factor are "heartbeat" and "perspiration", there is a need to ensure that a variable such as "lethargy" does not load onto this factor. There should be limit to the number of variables that should represent or be a component of the factor for cross-loading; this is to be ensured so that each factor will define a different jumble of interconnected variables.

\section{Communality}

Communality can be defined as the percentage measure of a variable's variation that is being explained by the factors. It is the portion of variance an initial variable that is shared with all other variables that is included in the analysis. A relatively higher communality implies that a variable has much in general with the other variables taken as a group of factor as noted by Islam \& Mamun. ${ }^{51}$ Furthermore, the communality measures the presence of variance in a given variable that is explained by all the factors mutually and may be inferred as the consistency of the indicator.

\section{Eigen values}

Eigenvalues are also referred to as roots characteristic. For a given measure of factor, Eigenvalue for a particular factor measures the variance in all the variables that are accounted for by that particular factor. The Eigenvalues ratio is the proportion of explanatory factors that concerns the variables. If there is a low Eigenvalue factor, then it is contributing little to the variance explanation in the variables and may be left as redundant as compared to more important factors. Perhaps the most frequently used extraction approach is the root greater than one criterion. Kasier ${ }^{52}$ suggested that this criterion retains those components whose Eigenvalues are higher than one (1). The underlying principle behind this criterion is that any element that is being contained in the system should account for extra variance any on its own than other variables in the standardized test score space.

\section{Scree plots}

According to Hackett \& Foxall, ${ }^{53}$ scree plots are produced by scheming the number of factors alongside their relevant eigenvalue. Scree plot is a diagrammatic representation of the eigenvalues as against all the factors. The diagram is very useful for shaping and determining the number of factors that should be retained.

\section{Factor extraction}

There are several ways to conduct factor analysis; they are analysis involving unweighted least squares; alpha factoring; principal components; maximum likelihood; generalized least squares; principal axis factoring; and image factoring, and the choice of methods which comprises of covariance matrix or a correlation matrix.

\section{Factor rotation}

Factors are rotated for improved interpretation of variables because unrotated factors are used to be very ambiguous. In fact, the aim of the factor rotation is to reach the most favourable simple structure which attempts to have each variable load on a some factors as possible although maximizes the figure of high loadings on each variable (Rummel, 1970). The interpretation of factors has the tendency of being improved through the rotation. Rotation of factors help maximizes the loading of each variable on one of the factors extracted whilst minimizing the loading on all other factors. Rotation of factors is enhanced through the changing of absolute values of the variables whilst keeping their differential values constant. Quartmax, Varimax, and Equamax are the variant techniques of orthogonal rotation usually adopted for modification of factors when rotated.

Varimax method is most dominant among the variant techniques and is mostly adopted in the making of Principal Components Analysis (PCA). The system endeavour to rotated factors so that the variation of the squared factor loading is made large for a given factor. The choice of rotation is largely dependent on whether or not the researcher or analyst should choose one of the orthogonal rotations. For this study, Varimax was recommended. Also, Quartimax method is an orthogonal option that reduces the number of factors required for explaining each variable. This type of rotation is mostly generated from a general factor on which most variables are loaded to a high or average level. Equimax method attempts to achieve a simple configuration regarding both the rows and columns in matrix of the factor loading.

\section{Statistical validity (Kaiser Meyer Olkin)}

According to George and Mallery (2003), Kaiser Meyer Olkin (KMO) is used to determine whether or not the distribution of numerical value is proper or adequate for performing factor analysis. The determination of KMO that is between 0.9 and 0.8 is excellent, $\mathrm{KMO}$ that is between 0.7 and 0.6 is very good, $\mathrm{KMO}$ that is between 0.6 and 0.5 is good, $\mathrm{KMO}$ that is below 0.5 is not good and unacceptable. Hence, factor analysis would be useless and pointless with an identity matrix. George and Mallery also noted that a significance value that is not up to 0.05 implies that the data do not generate an identity matrix and are thus normal, suitable and acceptable multivariate for factor analysis.

\section{Model equation}

In the situation where the observed variables are denoted $X_{l}, X_{2} \ldots$ $X_{n}$, the dominant variables are $F_{p}, F_{2} \ldots F_{m}$ and the unique variables are $U_{1}, U_{2} \ldots U_{n}$, the variables may be expressed as linear functions of the variables:

$$
\begin{aligned}
& X_{1}=a_{11} F_{1}+a_{12} F_{2}+a_{13} F_{3}+\ldots+a_{1 m} F_{m}+a_{1} U_{1} \\
& X_{2}=a_{21} F_{1}+a_{22} F_{2}+a_{23} F_{3}+\ldots+a_{2 m} F_{m}+a_{2} U_{2} \\
& \ldots \\
& X_{n}=a_{n 1} F_{1}+a_{n 2} F_{2}+a_{n 3} F_{3}+\ldots+a_{n m} F_{m}+a_{n} U_{n}
\end{aligned}
$$

The equations represented above are regression equations; and factor analysis enhances the examination of which equation best reproduce the observed variables from the coefficients $a_{11}, a_{12} \ldots a_{n m}$. The coefficients $a_{11}, a_{12} \ldots a_{n m}$ are referred to as weights in the same way as regression coefficients because of some reasons which are:

i. The variables are standardised; and

ii. The constant is zero, therefore it is not shown.

A good example is the coefficient $a_{11}$ that shows the effect on variable $X_{1}$ of a one-unit increase in $F_{1}$. In factor analysis, the coefficients are referred to as loadings (a variable is said to load on a factor) and, when the factors are uncorrelated, they also show the correlation between each variable and a given factor. In the model above, $a_{11}$ is the loading for variable $X_{1}$ on $F_{1}, a_{23}$ is the loading for variable $X_{2}$ on $F_{3}$, etc. When the coefficients are uncorrelated, this 
implies that the factors are uncorrelated, and the sum of the squares of the loadings for variable $X_{1}$, namely $a_{112}+a_{122}+\ldots+a_{132}$, shows the proportion of the variance of variable $X_{1}$ which is accounted for by the common factors. This is referred to as communality. The outsized the communality for each variable, the more successful a factor analysis solution. Also, the bigger the incongruity, the less flourishing the factor solution will be when preserving the information in the unique correlation matrix.

\section{Results and discussion}

\section{Socio-economic characteristics of respondents}

For socio-economic characteristic of the respondents sampled for the study, the variables considered were: gender, income status, age, educational status. The gender of the respondents revealed that $69.1 \%$ were male and $30.9 \%$ were female. This indicates that majority of the respondents travelling by air at the domestic terminal of Murtala Muhammed Airport were male. This may be as a result of air mobility variation. The activities of men in terms of air mobility or air travel vary differently along gender lines. There is discernible differentiation in gender pattern regarding the behavioural pattern of passenger during travel; this can be traceable to several factors that ranges from income level, age level, time, societal perception, family size, distance, among all.

The income status indicates that 29.7 percent earn more than $\$ 500,000$ in a month, 49.2 percent earned between $\$ 300,000$ and $\$ 500,000,16.8$ percent earned between $\$ 100,000$ and $\$ 299,999$ and 4.3 percent earned less than 100,000 . The analysis depicts that majority of the respondents earn good income such that they can afford air travel. This is an implication that high-income earners have a tendency of making more trips by air than low-income earners, and it justifies that air transport is luxury.

Examining the age level of respondents is crucial to the present study. From the study, it was revealed that 7.7 percent of questionnaire respondents were in between the age range of 20-30 years, 54.6 percent were in between the age range of $30-40$ years, 28.8 percent were in between the age range of 40-50 years and 8.9 percent were above the age range of 50 years. Hence, most respondents for this study were in between the age range of 30-50 years. This is an implication that the age range has significant influence on the expedition for regional or location complementarity, intervening opportunity, living and the justification for travel. This age range is an active or working age range where people in that category are proficient, skilful and have the ability to cope with the complex issues of human surroundings. With respect to the educational significance of the passengers, it was identified that majority of the respondents at about 55.7 percent were holder of higher institution certificate. The implication of this percent is that respondents have enough prerequisites to reveal sufficient details regarding the level of airport service.

\section{Factor analysis output}

From the questionnaire, thirty-nine (39) airport services were listed out from the SKYTRAX indices regarding the satisfaction of airport passengers. From the airport service indices, the airport services that influence the satisfaction of airport passengers were identified, selected and adapted based on the named specific aspects. The questions used for the survey were developed or coined out in such a way that the data collected could be further adopted while employing factor analysis and achieving the number of complex factors. Thirtynine factors were offered to respondents to evaluate each factor that influences their satisfaction with airport services. The ten-point scale was adapted to determine the airport service factors considered for measurement, whereby " 1 " correspond to the airport services that are not influencing satisfaction level at all, while "10" correspond to the airport services that extremely influenced the satisfaction level of passengers.

According to Coelho \& Esteves; $;{ }^{54}$ Hill et al., ${ }^{55}$ the 10-point scales were principally acknowledged as the most suitable for conducting research on customer satisfaction. In order to determine the direction and strength of the nexus among the variables, correlation coefficients were employed, which further gives opportunity for simultaneous manipulation with different types of data. In continuation, factor analysis was conducted through the principal component analysis nonetheless; factor rotation was executed with the Varimax method and Kaiser Normalization method. The Kaiser-Meyer-Olkin (KMO) test was conducted to substantiate the adequacy of sampling size that will be most suitable for conducting factor analysis.

Table 2 shown above contained the factor loadings of correlations connecting the variables and factors. In the practical sense, complex factors are generated through the combination of those listed variables or factors that have comparatively high loading factors after espousing the principal component analysis achieved by Varimax rotation. From the analysis, it is crucial to note that six (6) complex factors were revealed as they are major dimensions of all the thirty nine (39). The results give a lucid picture of what multifaceted factors or compounded factors should signify. The factors were grouped into eight classes. In each class, the most significant factors that satisfy airport passengers were obtained from factor analysis as presented below:

Staff Attitude: This consists of four complex variables, out of which three complex factors which comprises of the Friendliness of airport staff; Immigration staff attitude; and Language skills for airport staff were identified crucial.

Baggage Efficiency: This consists of four complex variables, out of which three complex factors which comprise of the Baggage delivery times; Priority baggage delivery efficiency; and Availability of luggage trolleys were considered crucial.

Ease of Finding: This consists of six complex variables, out of which two complex factors which comprise of the Efficiency of available public transport options; and Ease of transit through the airport was considered crucial.

Time Efficiency: This consists of four complex variables, out of which two complex factors which comprise of Immigration and queuing times; and Waiting times at security screening were considered crucial.

Airport Policy and Pricing: This consists of six complex variables, out of which three complex factors which comprise of the Security and safety standards; Choice of shopping, tax-free and other outlets; and Standard of physically impaired facilities were considered crucial.

Comfort Facility: This consists of six complex variables, out of which three complex factors which comprise of the Seating facilities throughout the terminal; Television and entertainment facilities; and Quiet areas, day rooms, rest area, hotel facilities were considered crucial.

Business Facilities: This consists of four complex variables, out of which three complex factors which comprise of the Internet facilities and WIFI availability; Business centre facility; and Bureau de change facility were considered crucial. 
Table 2 Factors affecting the satisfaction of airport passengers

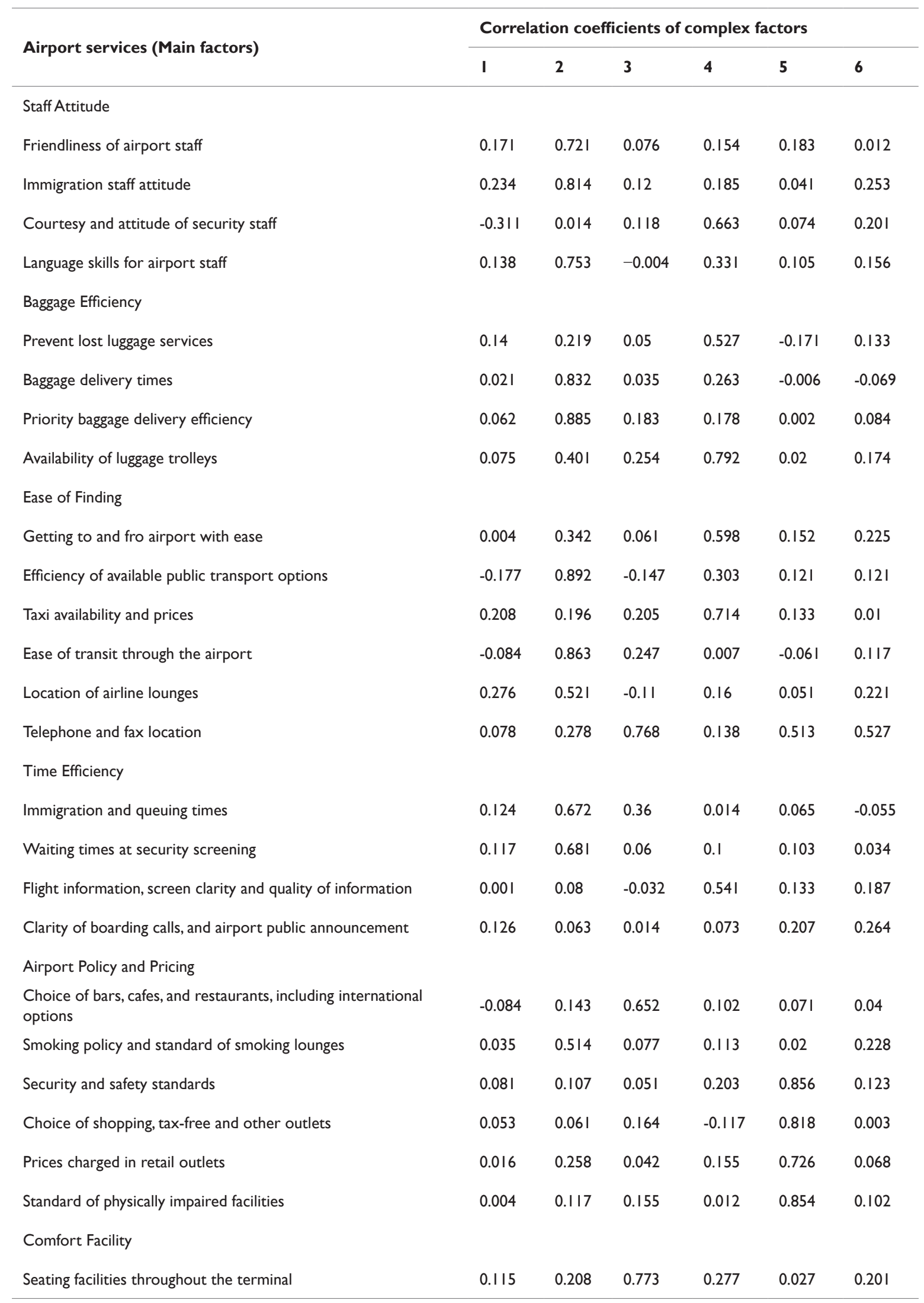


Table Continued

\begin{tabular}{|c|c|c|c|c|c|c|}
\hline \multirow{2}{*}{ Airport services (Main factors) } & \multicolumn{6}{|c|}{ Correlation coefficients of complex factors } \\
\hline & $\mathbf{I}$ & 2 & 3 & 4 & 5 & 6 \\
\hline Terminal signage facilities, boarding gates, transfer and arrivals & 0.282 & 0.352 & 0.237 & 0.111 & 0.255 & 0.034 \\
\hline Television and entertainment facilities & 0.186 & 0.131 & 0.815 & 0.241 & 0.116 & 0.134 \\
\hline Quiet areas, day rooms, rest area, hotel facilities & 0.087 & 0.162 & 0.784 & 0.357 & 0.271 & 0.158 \\
\hline Children play area facilities & 0.035 & 0.234 & 0.769 & 0.381 & -0.003 & 0.134 \\
\hline Check-in, and queuing facilities & 0.142 & 0.004 & 0.633 & 0.273 & 0.077 & 0.201 \\
\hline \multicolumn{7}{|l|}{ Business Facilities } \\
\hline Internet facilities and WIFI availability & 0.077 & 0.057 & 0.832 & 0.188 & 0.116 & 0.087 \\
\hline Business center facility & 0.163 & 0.315 & $0.74 I$ & 0.084 & 0.069 & 0.794 \\
\hline Bureau de change facility & 0.013 & 0.107 & 0.238 & 0.577 & 0.332 & 0.751 \\
\hline ATM facility & 0.058 & 0.126 & 0.235 & 0.684 & 0.017 & 0.264 \\
\hline \multicolumn{7}{|l|}{ Facilities for Cleanliness } \\
\hline Terminal comfort, ambiance, general designs and appearance & 0.073 & 0.733 & 0.23 & 0.156 & 0.137 & 0.259 \\
\hline Washroom and shower facilities & 0.201 & 0.214 & 0.751 & 0.234 & 0.027 & 0.272 \\
\hline Cleanliness of terminal, floor, seating, and public area & 0.109 & 0.173 & 0.192 & 0.732 & 0.021 & 0.165 \\
\hline Cleanliness of washroom facilities & 0.173 & 0.341 & -0.088 & -0.064 & 0.002 & -0.127 \\
\hline
\end{tabular}

Source: SPSS Version 20 (2020)

Facilities for Cleanliness: This consists of four complex variables, out of which three complex factors which comprise of the Terminal comfort, ambience, general designs and appearance; Washroom and shower facilities; and Cleanliness of the terminal, floor, seating, and public area were considered crucial.

Based on the eight factors identified, KMO test was coined out. The reason is because KMO test cannot emanate when entire thirty nine factors were loaded. From Table 3 below, the KMO result of 0.626 is very good and acceptable for performing factor analysis, and it is significant at 0.000 which implies that the data do not generate an identity matrix; also the data is normal, suitable and acceptable multivariate for factor analysis.

Table $3 \mathrm{KMO}$ and Bartlett's test

\begin{tabular}{lll}
\hline \multicolumn{2}{l}{ Kaiser-Meyer-Olkin Measure of Sampling Adequacy. } & $\mathbf{0 . 6 2 6}$ \\
\hline & Approx. Chi-Square & 2103.509 \\
Bartlett's Test of Sphericity & Df & 28 \\
& Sig. & 0 \\
\hline
\end{tabular}

Source: SPSS Version 20 (2020)

Among all the crucial complex factors, the following factors: Immigration staff attitude, Priority baggage delivery efficiency, Efficiency of existing public transport options, Immigration and queuing times, Security and safety standards, Television and entertainment facilities, Internet facilities and WIFI availability, and Washroom and shower facilities are most crucial airport services to passengers. Some of the factors revealed are in agreement with the studies of Fadare \& Adeniran, ${ }^{4}$ Sergejs \& Ksenija, ${ }^{1}$ Norazah,,${ }^{56}$ Archana \& Subha,${ }^{19}$ Correia et al. ${ }^{22}$ Park. ${ }^{9}$

\section{Conclusion}

This study examined complex factors influencing passengers' satisfaction at Murtala Muhammed Airport (MMA2), which is the domestic and only concessioned airport terminal in Nigeria. The study was supported by theoretical substantiations, and factor analysis was conducted to reveal the major categories of factors that do influence the satisfaction of airport passengers. The study adopted thirty-nine Skytrax indicators to list out the entire airport services which were blended in the questionnaire instrument to collect the required data at the airport terminal through convenience sampling technique. ${ }^{57-70}$ Out of six hundred and fifty-seven (657) questionnaires distributed, five hundred and fourteen (514) valid questionnaires were returned for data analysis.

From the primary data analyzed, the study find that the most crucial eight factors that do affect satisfaction of passengers in MMA2 are: Immigration staff attitude, Priority baggage delivery efficiency, Efficiency of public transport that are available, Immigration and queuing times, Security and safety standards, Television and entertainment facilities, Internet facilities and WIFI availability, and 
Washroom and shower facilities. From the findings, recommendations were suggested that among thirty nine airport services listed in the service benchmark for global airport, managers of MMA2 should provide quality services with respect to: Immigration staff attitude; Priority baggage delivery efficiency; Efficiency of available public transport options; Immigration and queuing times; Security and safety standards; Television and entertainment facilities; Internet facilities and WIFI availability; and Washroom and shower facilities as they are crucial to satisfying the passengers.

\section{Acknowledgments}

None.

\section{Conflicts of interest}

Authors declare that there is no conflict of interest.

\section{References}

1. Sergejs P, Ksenija I. Factor analysis of Passengers' Satisfaction at RIGA International Airport. Economics and Business. 2015;27(1):46-52.

2. Economic Benefits from Air Transport in Nigeria. Oxford Economics: Oxford, UK; 2012

3. National Civil Aviation Policy (NCAP); 2013.

4. Adeniran AO, Fadare SO. Assessment of Passengers' Satisfaction and Service Quality in Murtala Muhammed Airport (MMA2), Lagos, Nigeria: Application of SERVQUAL Model. Journal of Hotel and Business Management. 2018;7(2):188.

5. Arif, M, Gupta A, Williams A. Customer Service in the Aviation Industry - An Exploratory Analysis of UAE Airports. Journal of Air Transport Management. 2013;32:1-7.

6. Saha GC, Theingi A. Service Quality, Satisfaction, and Behavioural Intentions: A Study of Low-Cost Airline Carriers in Thailand. Managerial Service Quality. 2009;19(3):350-372.

7. Aksoy S, Atilgan E, Akinci S. Airline Services Marketing by Domestic and Foreign Firms: Differences from the Customers' Viewpoint. Journal of Air Transport Management. 2003;9(6):343-351.

8. Pakdil F, Aydin O. Expectations and Perceptions in Airline Services: An Analysis using Weighted SERVQUAL Scores. Journal of Air Transport Management. 2007;13(4):229-237.

9. Park JW. Passenger Perceptions of Service Quality: Korean and Australian Case Studies. Journal of Air Transport Management. 2007;13(4):238-242

10. Sultan F, Simpson MC. International Service Variants: Airline Passenger Expectations and Perceptions of Service Quality. Journal of Service Marketing. 2000;14(3):188-216.

11. Adam L, John ML. Passenger Service Quality Expectations as Perceived by Long Haul Airline Managers in South Africa. African Journal of Business Management. 2011;5(29):11662-11675.

12. Nimalathasan B. Factor Analysis: Nature, Mechanism and Uses in Social and Management Research. Journal of Cost and Management Accountant Bangladesh. 2009;XXXVII (2):15-25.

13. Spearman C. General Intelligence, Objectively Determined and Measured. American Journal of Psychology. 1904;15(20):1293.

14. Aidan G, Wright C. The Current State and Future of Factor Analysis in Personality Disorder Research. American Psychological Association. 2017;8(1):14-25.
15. Dolnicar S, Grabler K, Grün B, et al. Key Drivers of Airline Loyalty. Tourism Management. 2011;32(5):1020-1026.

16. Gilbert D, Wong R. Passenger Expectations and Airlines Services: a Hong Kong Based Study. Tourism Management, 2003;24(5):519-532.

17. Johnston R. The determinants of service quality: satisfiers and dissatisfiers. International Journal of Service Industry Management. 1995;6(5):53-71.

18. Adikariwattage V, De Barros AG, Wirasinghe SC, et al. Airport Classification Criteria Based on Passenger Characteristics and Terminal Size. Journal of Air Transport Management. 2012;24:36-41.

19. Archana R, Subha MV. A Study on Service Quality and Passenger Satisfaction on Indian Airlines. International Journal of Multidisciplinary Research. 2012;2(2):50-63.

20. Fadare SO, Adeniran AO. Comparative analysis of publicly operated airport terminal and concessioned airport terminal in Lagos, Nigeria. Discovery. 2018;54(272):304-318.

21. Gandomi A, Zolfaghari S. The profitability of Loyalty Reward Programs: An Analytical Investigation. Omega. 2013;41(4):797-807.

22. Correia AR, Wirasinghe SC, De Barros AG. Overall Level of Service Measures for Airport Passenger Terminals. Transportation Research Part A. 2008;42(2):330-346.

23. De Barros AG, Somasundaraswaran AK, Wirasinghe SC. Evaluation of Level of Service for Transfer Passengers at Airports. Journal of Air Transport Management. 2007;13(5):293-298.

24. Dale F, Brian M. Passengers' Expectations of Airport Service Quality. Journal of Services Marketing. 2007;21(7):492-506.

25. Gupta A, Arif M, Williams A. Customer Service in Aviation Industry - An Exploratory Analysis of UAE Airports. Journal of Air Transport Management. 2013;32:1-7.

26. Sung-Oun O, Jin-Woo Park. A Study on Importance and Satisfaction of Airport Selection Attributes: Focus on Gimpo International Airport and Incheon International Airport. International Journal of Business and Social Science. 2014;5(10):64-70.

27. Anastasia C. Passengers'satisfaction on facility services in terminal 2 of Tampere Airport. Published Undergraduate Thesis at Tampere University of Applied Sciences; 2014. 1-61 p.

28. Ben AO, Adebola GA. Determinants of Customers' Satisfaction in the Nigerian Aviation Industry Using Analytic Hierarchy Process (AHP). Model.Acta Universitatis Danubius. Economica. 2014;10(4):107-126.

29. Thomas KO. Users' Perceptions of Service Quality in Murtala Muhammed International Airport (MMIA), Lagos, Nigeria. Journal of Marketing and Consumer Research. 2014;3:48-53.

30. Ming-kei C, Yui Yip L. Travelers' perception on Airport Satisfaction. Journal of Business \& Economic Policy. 2016;3(2):55-60.

31. James AA, Binuyo OA. Is Service Quality a Correlate of Passengers' Satisfaction? Evidence from Nigerian Airports. International Journal of Marketing Studies. 2016;8(6):128-140.

32. Adeniran AO, Stephens MS. Gap Analysis of Service Quality Delivery in the Murtala Muhammed International Airport (MMIA), Lagos, Nigeria. SSRG International Journal of Industrial Engineering (SSRGIJIE). 2019;6(2):1-6.

33. Henry GT. Practical Sampling $10^{\text {th }}$ ed. Newbury Park: Sage Publications; 1990

34. Saunders M, Lewis P, Thomhil A. Research Methods for Business Students. $6^{\text {th }}$ ed; 2012. 
35. Zikmund WG. Business Research Methods. $6^{\text {th }}$ ed. The Dryden Press Harcourt College Publishers; 2003. 389 p.

36. Guilford JP. The Nature of Human Intelligence. NY: McGraw-Hill; 1967.

37. Catell RB, Eber HW, Tatsuoka MM. The Handbook for the Sixteen Personality Factor Questionnaire. Champaign, IL: Institute for Personality and Ability Testing; 1970.

38. Mugenda OM, Mugenda AG. Research Methods: Quantitative and Qualitative Approaches. Acts Press: Nairobi; 2003.

39. Black WC, Hair FJ, Tatham RL, et al. Multivariate Data Analysis. Upper Saddle River, NJ: Prentice-Hall; 2007.

40. Warne RT, Larsen R. Evaluating a Proposed Modification of the Guttman Rule for Determining the Number of Factors in an Exploratory Factor Analysis. Psychological Test and Assessment Modeling. 2014;56:104-123.

41. Dess G, Davis P. Generic Strategies as Determinants of Strategic Group Membership and Organisational Performance. Academy of Management Journal. 1984;27(3):463-482.

42. Thrustone LL. Primary Metal Abilities. Psychometric Monographs, I. Chicago: University of Chicago Press; 1938.

43. Hallquist MN, Wright AGC. Mixture Modelling Methods for the Assessment of Normal and Abnormal Personality, Part I: Crosssectional models. Journal of Personality Assessment. 2014;96(3):256268.

44. Jöreskog KG, Sörbom D. Advances in Factor Analysis and Structural Equation Models. Cambridge, MA: Abt Books; 1979.

45. Asparouhov T, Muthén B. Exploratory Structural Equation Modeling Structural Equation Modeling. 2009;16:397-438.

46. Debasish SS. Exploring Customer Preference for Life Insurance in India: Factor Analysis Method. Vilakshan. 2004;1:1.

47. Gorsuch RL. Factor Analysis (2 ${ }^{\text {nd }}$ ed.). Hillsdae NJ: Erlbaum; 1983.

48. Costello AB, Osborne JW. Best Practices in Exploratory Factor Analysis: Four Recommendations for Getting the most from your Analysis. Practical Assessment, Research and Evaluation. 2005;10(7):1-9.

49. Kline P. An Easy Guide to Factor Analysis. New York, NY: Routledge; 1994.

50. Islam N, Mamun MZ. Factors for Not Buying Life Insurance Policies in a Developing country: A Case of Bangladesh. Journal of Business Administration. 2005;1(2):31.

51. Kasier HF. The Varimax criterion for analytic rotation in Factor Analysis. Psycometrica. 1958;23:187.

52. Hackett PMW, Foxall GR. A Factor Analytic Study of Consumers Location Specific Values: A Traditional High Street and a Modern Shopping Mall: In Hooley Graham J, Hussey MK. (eds). Quantitative Methods in Marketing. London: International Thomson Business Press; 1999. 317-336 p.

53. Coelho SP, Esteves PS. The Choice between a Five-Point and a TenPoint Scale in the Framework of Customer Satisfaction Measurement. International Journal of Market Research. 2007;49(3):313-339.
54. Hill N, Roche G, Allen R. Customer Satisfaction: The Customer Experience through the Customer's Eyes. The Leadership Factor 2007. $125 \mathrm{p}$

55. Norazah MS. Passenger Satisfaction with Airline Service Quality in Malaysia: A Structural Equation Modeling Approach. Research in Transportation Business \& Management. 2014;10:26-32.

56. Quality of Service at Airports: Standards and measurements. ACI Europe World Headquarters: Geneva, Switzerland; 2000.

57. Arblaster M. The Design of Light-Handed Regulation of Airports: Lessons from Experience in Australia and New Zealand. Journal of Air Transport Management. 2014;38:27-35.

58. Child D. The Essentials of Factor Analysis. (3 ${ }^{\text {rd }}$ ed.) New York, NY: Continuum International Publishing Group; 2006.

59. Comrey LA, Lee HB. A First Course in Factor Analysis (2 ${ }^{\text {nd }}$ ed.) Hillside, NJ: Lawrence Erlbaum Associates; 1992.

60. Correia RA, Wirasinghe SC. Development of Level of Service Standards for Airport Facilities: Application to Sao Paulo Internationa Airport. Journal of Air Transport Management, 2007;13(2):97-103.

61. Cureton EE, D'Agostino RB. Factor Analysis: An Applied Approach. Hillsdale, NJ: Erlbaum; 1983.

62. De Nicola A, Gitto S, Mancuso P. Airport Quality and Productivity Changes: A Malmquist Index Decomposition Assessment Transportation Research Part E: Logistics and Transportation Review. 2013;58:67-75.

63. Lubbe B, Douglas A, Zambellis J. An Application of the Airport Service Quality Model in South Africa. Journal of Air Transport Management. 2011;17(4):224-227.

64. MacCallum RC, Widaman KF, Zhang S, et al. Sample Size in Factor Analysis. Psychological Methods. 1999;4(1):84-99.

65. Pabedinskaite A, Akstinaite V. Evaluation of the Airport Service Quality. Procedia-Social and Behavioral Sciences. 2014;110: 398-409.

66. Park J, Robertson R, Wu C. The Effect of Airline Service Quality on Passengers' Behavioural Intentions: A Korean Case Study. Journal of Air Transport Management. 2004;10(6):435-439.

67. Steven AB, Dong Y, Dresner M. Linkages between Customer Service, Customer Satisfaction and Performance in the Airline Industry: Investigation of Non-Linearities and Moderating Effects. Transportation Research Part E: Logistics and Transportation Review. 2012;48(4):743-754.

68. The 2015 Domestic Aviation Industry Passengers' Satisfaction Survey Report.

69. Wittman MD. Are Low-Cost Carrier Passengers Less Likely to Complain about Service Quality? Journal of Air Transport Management. 2014;35:64-71.

70. Xiao W, Paul DB, Mengnan H. Customer-Satisfaction Analysis at San Francisco International Airport. International Journal of Management Studies. 2015;2(1):1-12. 